\title{
MODEL PEMBELAJARAN EKSPOSITORY BERBANTUAN MEDIA AUDIO VISUAL UNTUK MENINGKATKAN HASIL BELAJAR BAHASA INDONESIA
}

\author{
Desak Nyoman Puspaeni \\ SMPN 2 Banjarangkan \\ Email: desaknyomanpuspaeni@gmail.com
}

\begin{abstract}
ABSTRAK
SMP Negeri 2 Banjarangkan merupakan lokasi diadakan penelitian tindakan kelas. Tujuan penulisan penelitian tindakan kelas ini adalah untuk mengetahui apakah model pembelajaran Ekspository berbantuan media Audio Visual dapat meningkatkan Hasil belajar siswa. Penelitian ini dilaksanakan di Sekolah Menengah Pertama Negeri 2 Banjarangkan di Kelas VIII.A yang kemampuan siswanya untuk mata pelajaran Bahasa Indonesia rendah. Metode pengumpulan datanya adalah tes hasil belajar. Metode analisis datanya adalah deskriptif. Hasil yang diperoleh dari penelitian ini adalah model pembelajaran Ekspository berbantuan media Audio Visual dapat meningkatkan hasil belajar siswa. Ini terbukti dari hasil yang diperoleh pada awalnya 69,74 pada siklus I menjadi 77,83 dan pada siklus II menjadi 82,17. Kesimpulan yang diperoleh dari penelitian ini adalah model pembelajaran Ekspository berbantuan media Audio Visual dapat meningkatkan hasil belajar Bahasa Indonesia siswa kelas VIII.A Semester II tahun pelajaran 2018/2019 di Sekolah Menengah Pertama Negeri 2 Banjarangkan.
\end{abstract}

Kata Kunci : Model pembelajaran ekspository, media audio visual, hasil belajar

\section{ABSTRACT}

SMP Negeri 2 Banjarangkan is a location for classroom action research. The purpose of writing this class action research is to find out whether the Expository learning model aided by Audio Visual media can improve student learning outcomes. This research was conducted at SMP Negeri 2 Banjarangkan in Class VIII.A where the ability of students for Indonesian subjects was low. Data collection method is a test of learning outcomes. The data analysis method is descriptive. The results obtained from this study are expository learning models assisted with audio visual media can improve student learning outcomes. This can be seen from the results obtained initially at 69.74 in the first cycle to 77.83 and in the second cycle to 82.17. The conclusion obtained from this study is that expository learning models assisted by Audio Visual media can improve the learning outcomes of Indonesian students in class VIII. Semester II of the 2018/2019 academic year at SMP Negeri 2 Banjarangkan.

Keywords: expository learning model, audio visual media, learning outcomes

\section{PENDAHULUAN}

Dalam rangka mengembangkan kemampuan intelektual, sosial dan emosional siswa mata pelajaran Bahasa Indonesia berperan penting sebagai kunci menuju keberhasilan dalam mempelajari suatu bidang tertentu. Fungsi mata pelajaran Bahasa Indonesia adalah sebagai suatu bidang kajian untuk mempersiapkan siswa mampu merefleksikan pengalamannya sendiri dan pengalaman orang lain, mengungkapkan gagasangagasan dan perasaan serta memahami beragam nuansa makna, sedang kegunaannya adalah untuk membantu siswa mengenal dirinya, budayanya, budaya orang lain, mengemukakan gagasan dan perasaan, berpartisipasi dalam masyarakat, membuat keputusan yang bertanggung jawab pada tingkat pribadi, 
sosial, menemukan serta menggunakan kemampuan analitik dan imajinatif yang ada dalam dirinya. Di samping itu sebagai seorang guru juga diperlukan untuk mampu menerapkan beberapa metode ajar sehingga paradigma pengajaran dapat dirubah menjadi paradigma pembelajaran (Depdiknas, 2007). Paradigma tersebut menyangkut bagaimana guru memberikan kesempatan agar siswa secara aktif membangun pengetahuannya sendiri dan bukan menerima secara pasif informasi yang disampaikan guru.

Secara umum penyebab rendahnya hasil belajar siswa adalah: faktor dari dalam guru itu sendiri seperti kemauan menyiapkan bahan yang lebih baik, kemauan guru itu sendiri untuk menerapkan metode-metode ajar yang telah didapat di bangku kuliah. Selain itu guru juga kurang mampu untuk dapat mengembangkan keterampilan mengajar yang dapat menarik perhatian siswa dan merangsang siswa untuk belajar.

Segudang harapan dipihak guru yang telah disampaikan ternyata tidak mampu dipenuhi. Akibatnya muncul kesenjangan yaitu hasil belajar Bahasa Indonesia siswa kelas VIII.A Semester II SMP Negeri 2 Banjarangkan tahun pelajaran 2018/2019 menjadi rendah dengan rata-rata kelas 69,74 dan ketuntasan 39,13\%. Hal ini tidak sesuai dengan apa yang diharapkan di SMP Negeri 2 Banjarangkan dimana ketuntasan yang diharapkan adalah minimal 85,00\%.

Adanya kesenjangan antara harapan-harapan yang telah disampaikan dengan kenyataan lapangan yang sangat jauh berbeda, dalam upaya memperbaiki mutu pendidikan utamanya pada mata pelajaran Bahasa Indonesia, sangat perlu kiranya dilakukan perbaikan cara pembelajaran. Salah satunya adalah perbaikan pembelajaran dengan menggunakan model pembelajaran ekspository berbantuan media audio visual. Oleh karenanya penelitian ini sangat penting untuk dilaksanakan dalam rangka memperbaiki kualitas proses dan hasil belajar siswa.

Gambaran upaya yang akan dilakukan peneliti untuk menyelesaikan masalah tersebut adalah dengan merumuskan masalah penelitian sebagai berikut: Apakah model pembelajaran Ekspository berbantuan media audio visual dapat meningkatkan hasil belajar Bahasa Indonesia siswa kelas VIII.A SMP Negeri 2 Banjarangkan.

Tujuan yang disusun dalam penelitian ini adalah untuk: mengetahui seberapa tinggi peningkatan hasil belajar siswa akan terjadi setelah diterapkan model pembelajaran Ekspository berbantuan media audio visual dalam pembelajaran.

Manfaat Teoritis penelitian: sebagai acuan dalam memperkaya teori dalam rangka peningkatan kokpetensi guru. Sedangkan Manfaat praktis penelitian ini diharapkan bermanfaat: 1) Bagi kepala sekolah, membantu mengatasi masalah dalam proses pembelajaran dengan menyarankan guru-guru menggunakan model pembelajaran dalam penelitian ini; 2) Bagi guru, meningkatkan kreativitas mencari model pembelajaran yang efektif digunakan dalam proses pembelajaran untuk memperkaya teori dalam rangka peningkatan kompetensi guru; 3) Bagi siswa, meningkatkan hasil belajar, belajar lebih bermakna, pengetahuan yang didapat melalui proses pembelajaran tersebut dapat bertahan lebih lama.

(Sanjaya, 2006) menamakan metode ekspository dengan istilah strategi 
pembelajaran langsung (Direct

Instruction). Karena dalam hal ini siswa tidak dituntut untuk menemukan materi itu. Materi pelajaran seakan-akan sudah jadi. Oleh karena metode ekspository lebih menekankan kepada proses bertutur, maka sering juga dinamakan istilah metode chalk and talk.

Strategi pembelajaran ekspository adalah strategi pembelajaran yang menekankan kepada proses penyampaian materi secara verbal dari seorang guru kepada sekelompok siswa dengan maksud agar siswa dapat menguasai materi pelajaran secara optimal (Sanjaya, 2006). Strategi Pembelajaran ekspository akan efektif apabila: (1) Guru akan menyampaikan bahan-bahan baru serta kaitannya dengan yang akan dan harus dipelajari siswa; (2) Apabila guru menginginkan agar siswa mempunyai gaya model intelektual tertentu,misalnya agar siswa bisa mengingat bahan pelajaran,sehingga ia akan dapat mengungangkapkannya kembali manakala diperlukan; (3) Jika bahan pelajaran yang akan diajarkan cocok untuk dipresentasikan, artinya dipandang dari sifat dan jenis materi pelajaran memang materi itu hanya mungkin dapat dipahami oleh siswa manakala disampaikan oleh guru,misalnya materi pelajaran hasil penelitian berupa data-data khusus; (4) Jika ingin membangkitkan keingintahuan siswa tentang topic tertentu; (5) Guru menginginkan untuk mendemonstrasikan suatu teknik atau prosedur,biasanya merupakan suatu teknik atau prosedur tertentu untuk kegiatan praktik; (6) Apabila seluruh siswa memiliki tingkat kesulitan yang sama sehingga guru perlu menjelaskan untuk seluruh siswa; (7) Apabila guru akan mengajar pada sekelompok siswa yang rata-rata memiliki kemampuan rendah; (8) Jika lingkungan tidak mendukung untuk menggunakan strategi yang berpusat pada siswa,misalnya tidak adanya sarana dan prasarana yang dibutuhkan; (9) Jika tidak memiliki waktu yang cukup untuk menggunakan pendekatan yang berpusat pada siswa.

Model pembelajaran yang berpusat pada guru ini memiliki keunggulan: 1) bahan belajar dapat disampaikan secara tuntas, 2) dapat diikuti oleh siswa dalam jumlah besar, 3) pembelajaran dapat dilaksanakan sesuai dengan alokasi waktu yang ditetapkan, 4) target materi relatif mudah dicapai. Sedangkan kelemahannya yang dapat terjadi adalah: 1) membosankan, 2) keberhasilan perubahan sikap dan prilaku peserta didik relatif sulit diukur, 3) kualitas pencapaian tujuan belajar yang telah ditetapkan adalah relatif rendah karena pendidik sering hanya mengejar target waktu untuk menghabiskan target materi pembelajaran, dan pembelajaran kebanyakan menggunakan ceramah dan jawab (Sudjana, 2005:39) Jadi Kelebihan dari pendekatan ini adalah mudah dilakukan karena tanpa memerlukan suatu rangkaian khusus pembelajaran dapat diterapkan pada materi yang mudah diakses siswa yang lebih bersifat hafalan. Sementara kelemahannya adalah: 1) kurang memberikan kesempatan bagi berkembangnya kemampuan eksplorasi, kreativitas, kemandirian dan sikap kritis siswa. 2) cenderung menimbulkan sikap pasif pada siswa karena terbiasa menerima. 3) kegiatan cenderung bersifat mekanistis. Jadi model pembelajaran ekspository tidak dilandasi oleh paham konstruktivisme (Sanjaya, 2006).

Media berasal dari bahasa latin merupakan bentuk jamak dari "Medium" yang secara harfiah berarti "Perantara" 
atau "Pengantar" yaitu perantara atau pengantar sumber pesan dengan penerima pesan. Dalam dunia pembelajaran, terdapat sejumlah definisi tentang media. Media pembelajaran adalah sarana komunikasi dalam bentuk cetak maupun pandangdengar, termasuk teknologi perangkat keras (Sudrajat, 2008a). Media pembelajaran yang digunakan dalam kegiatan pembelajaran dapat mempengaruhi efektivitas pembelajaran. Pada mulanya, media pembelajaran hanya berfungsi sebagai alat bantu guru untuk mengajar yang digunakan adalah alat bantu visual. Sekitar pertengahan abad ke20 usaha pemanfaatan visual dilengkapi dengan digunakannya alat audio, sehingga lahirlah alat bantu audio-visual. Sejalan dengan perkembangan ilmu pengetahuan dan teknologi (IPTEK), khususnya dalam bidang pendidikan, saat ini penggunaan alat bantu atau media pembelajaran menjadi semakin luas dan interaktif, seperti adanya komputer dan internet (Sudrajat, 2008b).

Pada hakikatnya bukan media pembelajaran itu sendiri yang menentukan hasil belajar. Ternyata keberhasilan menggunakan media pembelajaran dalam proses pembelajaran untuk meningkatkan hasil belajar tergantung pada (1) isi pesan, (2) cara menjelaskan pesan, dan (3) karakteristik penerima pesan. Namun peran guru dalam hal ini sangat dominan. Guru harus selalu merencanakan proses pembelajaran, bekerja sama dengan guruguru lain dan ahli media, guru dapat mengintegrasikan media ke dalam proses pembelajran sehingga dapat memperbesar perolehan (hasil mengajar) yang berdampak pada peningkatan hasil belajar siswa.

\begin{tabular}{rrr} 
Menurut & \multicolumn{2}{c}{ (Slameto, } \\
mengemukakan & bahwa kata & hasil
\end{tabular}

mempunyai arti "akibat kesudahan dari suatu ulangan atau ujian". Mengenai hasil belajar, (Slameto, 2000) menyatakan bahwa segala kegiatan atau usaha selalu mengakibatkan terjadinya perubahan tingkah laku. Kegiatan dan usaha untuk mencapai perubahan tingkah laku itu merupakan hasil belajar. Hasil belajar merupakan suatu puncak proses belajar, hasil belajar tersebut terutama berkat evaluasi guru, hasil belajar dapat berupa dampak pengajaran dan dampak pengiring dan manfaat bagi guru dan siswa (Dimyati \& Mudjiono, 2002).

\section{METODE PENELITIAN}

SMP Negeri 2 Banjarangkan merupakan lokasi dilakukan penelitian tindakan kelas. Sekolah ini terletak di Jalan Desa Nyalian Kecamatan Banjarangkan, Kabupaten Klungkung, Provinsi Bali. Sekolah ini sangat rindang karena tumbuh beberapa pohon pelindung. Lingkunganya sangat bersih karena masing-masing kelas sudah berisi bak sampah dan para siswa membantu dalam menjaga kebersihan sekolah.

Subjek penelitian ini adalah siswa kelas VIII.A SMP Negeri 2 Banjarangkan Tahun Pelajaran 2018/2019 Semester II yang terdiri dari 12 orang laki-laki dan 11 orang perempuan. Objek penelitian ini adalah peningkatan hasil belajar Bahasa Indonesia siswa kelas VIII.A SMP Negeri 2 Banjarangkan. Penelitian ini dilakukan dari bulan Januari 2019 sampai bulan Mei 2019. Peneliti memilih rancangan penelitian tindakan yang disampaikan oleh (Arikunto, Suharsimi: Supardi, 2006) seperti terlihat pada gambar. 


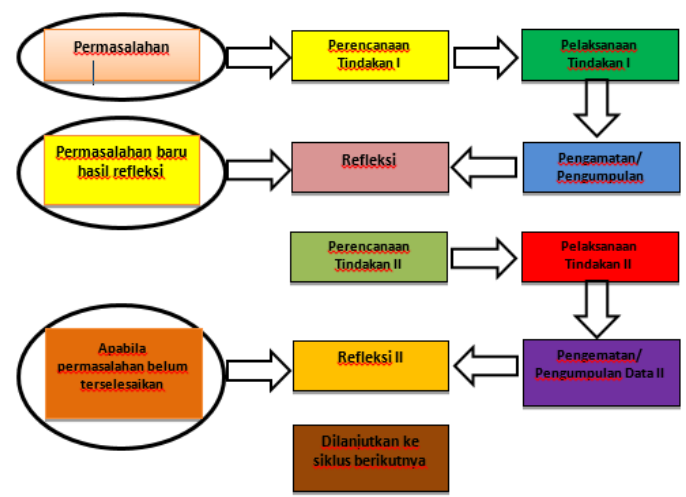

Gambar 1. Alur Penelitian Tindakan Kelas (Arikunto, Suharsimi: Supardi, 2006)

Dalam penelitian ini data yang diperoleh berupa hasil hasil belajar tindakan pembelajaran dengan pendekatan model pembelajaran ekspository berbantuan media audio visual, teknik pengumpulan datanya menggunakan cara tes hasil belajar. Data hasil belajar tindakan pembelajaran menggunakan pendekatan model pembelajaran ekspository adalah kualitatif, dan data kualitas pertanyaan dimensi konsep dalam pembelajaran menggunakan pendekatan model pembelajaran ekspository adalah kuantitatif, analisisnya menggunakan cara sederhana yaitu nilai hasil belajar Bahasa Indonesoa $=\frac{\text { skor perolehan }}{\text { skor maksimal }} \times 100$. jenis data tersebut ditarik kesimpulan secara deskriptif kualitatif. Hasil belajar yang diusulkan dalam penelitian ini, pada siklus I nilai rata-rata 78,00 dengan prosentase ketuntasan belajar sebesar $80 \%$ dan pada siklus II mencapai nilai 78,00 dengan prosentase ketuntasan belajar sebesar $85 \%$ atau lebih.

\section{HASIL PENELITIAN DAN}

\section{PEMBAHASAN}

\section{Hasil Penelitian}

Deskripsi yang dapat disampaikan untuk perolehan data awal adalah: dari 23 orang yang ada di kelas yang diteliti yaitu kelas VIII.A Semester II SMP Negeri 2 Banjarangkan tahun pelajaran 2018/2019 ada 14 orang siswa $(60,87 \%)$ belum tuntas karena memperoleh nilai di bawah KKM $(72,00), \quad 8$ orang siswa $(34,78 \%)$ memperoleh nilai sama dengan KKM dan seorang siswa $(4,35 \%)$ memperoleh nilai di atas KKM pada mata pelajaran Bahasa Indonesia di sekolah yaitu 72,00. Pencapaian tersebut memperoleh predikat sangat kurang. Data tersebut menunjukkan rendahnya hasil belajar Bahasa Indonesia di sekolah ini, sehingga peneliti sebagai guru di sekolah ini harus mengupayakan cara lain untuk membenahi proses pembelajaran menjadi lebih baik.

Dari 23 siswa menunjukkan ada 6 orang siswa mendapat nilai di bawah KKM adalah ${ }^{\frac{6}{23} \times 100=26,09 \%}$, ada 8 orang siswa mendapat nilai sama dengan KKM adalah $\frac{8}{23} \times 100=34,78 \%$ dan 9 siswa medapat nilai di atas KKM adalah $\frac{9}{23} \times 100=39,13 \%$ Ketuntasan hasil belajar siswa secara keseluruhan adalah 17 siswa atau $\frac{17}{23} \times 100=73,91 \%$. Pencapaian tersebut belum sesuai dengan indikator keberhasilan yang diharapkan. 


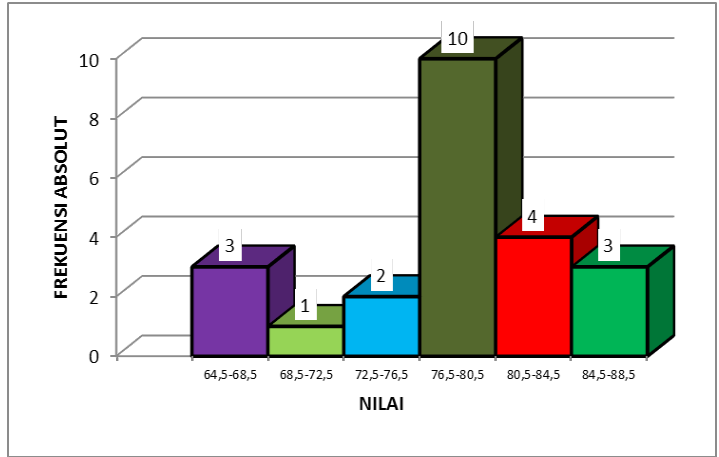

Gambar 2. Histogram Hasil Belajar Bahasa Indonesia Siswa Kelas VIII.A Semester II SMP Negeri 2 Banjarangkan Tahun Pelajaran 2018/2019 Siklus I

Kekurangan-kekurangan yang ada pada siklus I adalah: 1) Dibutuhkan waktu yang lebih lama dan berulang-ulang untuk menanamkan pengetahuan kepada siswa agar bermakna; 2) Tugas yang diberikan kurang maksimal, bahan yang disediakan guru belum menyentuh perasaan senang siswa yang akan memancing perhatian lebih mereka untuk mempelajarinya dan 3) Peneliti terlanjur memberikan materi yang agak sulit dan menyeluruh sehingga siswa tidak mampu menguasainya sekaligus, semestinya setelah memberikan secara global penguasaan materi diarahkan bagian demi bagian.

Kelebihan yang ada adalah: 1) Segala sesuatu yang memperlancar proses pelaksanaan bimbingan telah dipersiapkan secara maksimal; 2) Antusias peneliti untuk meningkatkan kemampuan siswa sangat tinggi dan 3) Belajar bagi siswa memang membutuhkan waktu, tetapi peneliti telah dengan sangat sabar membimbing agar bisa meningkatkan kemampuan mereka. Untuk meningkatkan kemampuan mereka, semua kekurangan yang telah disampaikan itu akan peneliti perbaiki pada siklus berikutnya.
Hasil

pelaksanaan

observasi/penilaian terhadap kemampuan siswa menerpa ilmu pada siklus II disampaikan sebagai berikut: Dari 23 siswa hasil belajar yang diperoleh yaitu: 20 orang siswa memperoleh nilai di atas $\operatorname{KKM}\left(^{\frac{20}{23} \times 100=86,96 \%}\right)$, seorang siswa mendapat nilai sama dengan KKM adalah $\frac{1}{23} \times 100=4,35 \%$

dan 2 siswa dinyatakan

belum tuntas adalah $\frac{2}{23} \times 100=8,70 \%$

karena memperoleh nilai di bawah KKM. Ketuntasan hasil belajar siswa secara keseluruhan adalah 21 siswa atau $\frac{21}{23} \times 100=91,30 \%$.

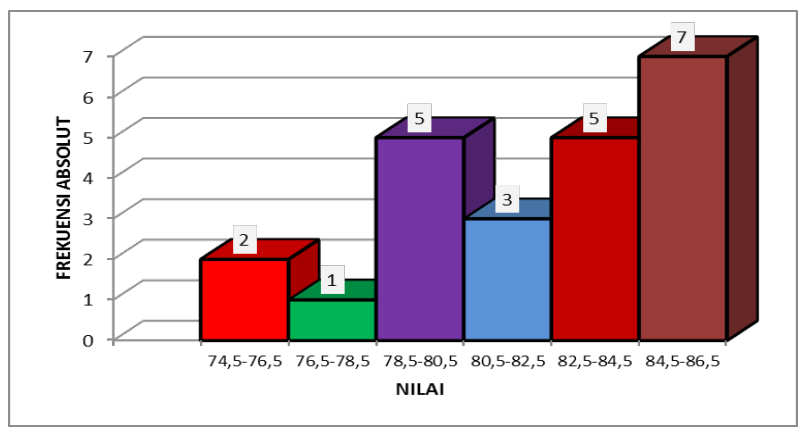

Gambar 3. Histogram Hasil Belajar Bahasa Indonesia Siswa Kelas VIII.A Semester II SMP Negeri 2 Banjarangkan Tahun Pelajaran 2018/2019 Siklus II

Semua hasil yang diperoleh pada Siklus II ini menunjukkan bahwa penelitian ini tidak perlu dilanjutkan lagi ke siklus berikutnya karena tuntutan keberhasilan penelitian ini sudah terpenuhi berdasar hasil analisis di atas. 


\section{Pembahasan}

Proses yang dilakukan dalam pembelajaran dengan model pembelajaran kuantum lebih mengkaji aspek kognitif, afektif dan psikomotor sebagai pedoman atas kemampuan siswa baik pikiran, prilaku maupun keterampilan yang dimiliki. Perbandingan nilai awal, nilai siklus I dan nilai siklus II, menunjukkan terjadinya kenaikan prestasi yang signifikan, yaitu dari rata-rata nilai awal adalah 69,74 naik di siklus I menjadi 77,83 dan di siklus II naik menjadi 82,17. Kenaikan ini menunjukkan upaya maksimal yang dilaksanakan peneliti demi peningkatan hasil belajar khususnya di SMP Negeri 2 Banjarangkan.

\section{SIMPULAN DAN SARAN}

Mengacu pada rendahnya hasil belajar siswa yang disampaikan pada latar belakang masalah dan upaya pemecahan yang dilakukan menggunakan model pembelajaran Ekspository untuk meningkatkan hasil belajar siswa, hasilnya tergambar dengan jelas seperti disampaikan pada bab sebelumnya. Melihat semua data yang telah disampaikan menjadi bukti bahwa pemilihan model pembelajaran yang dilakukan guru telah berhasil dengan sangat baik. Ini dapat dibuktikan dari hasil data awal ada 14 siswa $(60,87 \%)$ mendapat nilai di bawah KKM dan pada siklus I menurun menjadi 6 siswa $(26,09 \%)$ dan siklus II hanya 2 siswa $(8,70 \%)$ mendapat nilai di bawah KKM. Dari rata-rata awal 69,74 naik menjadi 77,83 pada siklus I dan pada siklus II naik menjadi 82,17. Dari data awal siswa yang memperoleh pengayaan hanya 9 siswa $(39,13 \%)$ sedangkan pada siklus I menjadi lebih banyak yaitu 17 siswa $(73,91 \%)$ dan pada siklus II menjadi banyak yaitu 21 siswa $(91,30 \%)$.

Model pembelajaran Ekspository dapat memberi jawaban yang diharapkan dalam penelitian tindakan kelas ini. Semua ini dapat dicapai adalah akibat kesiapan dan kerja keras peneliti. Sehingga dapat disimpulkan bahwa model pembelajaran ekspository berbantuan media audio visual dapat meningkatkan hasil belajar Bahasa Indonesia siswa kelas VIII.A pada Semester II Tahun Pelajaran 2018/2019 di SMP Negeri 2 Banjarangkan.

\section{DAFTAR PUSTAKA}

Arikunto, S \& Supardi, S. (2006). Penelitian Tindakan Kelas.

Depdiknas. (2007). Peraturan Menteri Pendidikan Nasional No. 41 Tahun 2007 Tanggal 23 November 2007.

Dimyati \& Mudjiono. (2002). Belajar dan Pembelajaran.

Sanjaya, W. (2006). Menajemen Penelitian Tindakan Kelas.

Slameto. (2000). Belajar dan FaktorFaktor yang Mempengaruhinya.

Sudrajat, A. (2008a). Konsep Media Pembelajaran.

http://akhmadsudrajat.wordpress.c om/2008/01/12/konsep-mediapembelajaran/

Sudrajat, A. (2008b). Metode Belajar Ekspository. http://www.kajianpustaka.com/20 $12 / 12 /$ metode-belajarekspository.html. \%0A\%0A 
